\title{
A Panel Data Analysis of Locational Determinants of Chinese and Indian Outward Foreign Direct Investment
}

\begin{abstract}
The upsurge of Chinese and Indian outward foreign direct investment (FDI) raises an unanswered question about locational determinants of direct investment from the two countries. Using an unbalanced bilateral FDI database, we find that Chinese and Indian FDI are attracted to countries with large market size, low GDP growth, high volumes of imports from China or India, and low corporate tax rates. We also find important differences between China and India. While Chinese FDI is drawn to countries with open economic regimes, depreciated host currencies, better institutional environments, and English speaking status, none of these factors are important for Indian FDI. Chinese FDI is also deterred by geographic distance and OCED membership. However, neither of these has any impact on Indian FDI.
\end{abstract}

Key words: Outward Foreign Direct investment, China, India.

Journal of Asia Business Studies, 2009, Volume 3, Number 2 


\section{A Panel Data Analysis of Locational Determinants of Chinese and Indian Outward Foreign Direct Investment}

\section{Introduction}

The rise of China and India is one of the defining events of the $20^{\text {th }}$ century. While China has captured the world's attention by its phenomenal FDI inflows and impressive GDP growth, India is swiftly developing its offshore IT outsourcing and other service sectors with its language and institutional advantages. The sheer size of the two countries, along with their rapid growth, means that some of the most important impacts are likely yet to be seen. With significant deregulation within the two countries on FDI abroad, those companies that have gained more confidence and accumulated more financial capital are now spreading their wings and investing overseas. Table 1 shows that from 1982 to 1992, Chinese FDI rose from 44 US\$ million to 4000 US\$ million, while India's outward FDI, beginning at only 1 US\$ million in 1982, rising rose slowly to 24 US\$ million in 1992 and then grew steadily from 82 to 2222 US\$ million in 2004.

\section{[INSERT TABLE 1 ABOUT HERE]}

The upsurge of Chinese and Indian FDI raises an unanswered question about the locational determinants of direct investment from the two countries. It is important to pursue such an understanding for several reasons. First, FDI from developing countries, especially big economies such as China and India, becomes a new source, alongside FDI from developed nations. MNEs from developing countries may foster positive spillovers because of narrower technological gaps between them and firms in developing nations (Battat and Aykut 2005). They are less corporatised and more informal than western models, and are often more appropriate to the host country context (Gelb 2005). In the light of significant decline in investments from developed nations, FDI from developing countries plays an important role in sustaining FDI flows to developing nations. Host country governments and agencies have an incentive to learn what attracts this type of investment in order to design their investment promotion policies. Furthermore, their investments may or may not have different determinants vis-à-vis FDI originating in 
developed nations. A systematic investigation will give us empirical evidence to take part in this debate. Third, a comparative study will enable us to explore whether Chinese and Indian FDI react to host characteristics differently and why they do so.

Using unbalanced panel data, we find that Chinese and Indian FDI are attracted to countries with large market size, low GDP growth, high volumes of imports from China or India, and low corporate tax rates. We also find important differences between China and India. While Chinese FDI is drawn to countries with open economic regimes, depreciated host currencies, better institutional environments, and English speaking status, but deterred by geographic distance and OCED membership; none of these factors is important for Indian FDI.

The remainder of the paper is set out as follows. Section 2 reviews literature on the locational determinants of FDI and studies on FDI from developing countries. Section 3 presents our research hypotheses. Section 4 explains the data, measurements and methodology. Section 5 reports the results. Finally, we summarise our findings, discuss policy implications, and acknowledge the limitations of the study.

\section{Literature review}

\subsection{Locational determinants of FDI}

As an important component of globalisation, FDI has grown far more rapidly than international trade during the last two decades (Gaston and Nelson 2002). Accordingly, there has been a vast amount of empirical literature developed around the issue of the forces attracting FDI. The literature is not only massive but also 'chaotic' (Chakrabarti 2001) because it has not been possible to arrange location-specific decisions of companies into a uniform theoretical pattern (Baniak et al 2003). However, according to Dunning's (1993) categorisation, most FDI can be classified into three types: resourceseeking, efficiency-seeking and market-seeking. As a result, most previous empirical studies have investigated the impact of the availability of natural resources, typically minerals, raw materials and agricultural products; the costs and quality of particular factor endowments; and the size and growth of domestic markets. Recently, scholars contend that FDI is also subject to basic macroeconomic trends, which bring some 'less 
conventional' variables, such as exchange rates, inflation rates, and debt levels, into the general framework. In addition, Dunning (2006) stressed the importance of the host institutional environment, such as taxes and fiscal incentive structure and legal and macroeconomic infrastructure, to inbound FDI.

While most empirical studies included 'conventional' variables, the inclusion of 'less conventional' ones differs from one to the other depending on the specific focus of the research. For example, Clegg and Scott-Green (1999) investigated the determinants of US and Japanese FDI into the European Community (EC) 1984-89 and found that the effects of conventional host characteristic variables demonstrated considerable varieties between groups of member countries. For example, throughout those countries in the EC with low labour costs, higher labour costs are positively associated with US and Japanese FDI; yet in countries with high labour costs, this effect diminishes. Both US and Japanese FDI react strongly to the market size of new entrants to the EC, but less so for existent EC member countries. Japanese FDI reacts more strongly to the EU integration compared to the US FDI due to its less established position in the EU. Corporate tax levels are less important in explaining FDI flows into the EC from outside. Focusing on the annual bilateral flows of FDI in the EU-15 members, Janicki et al. (2005) found the host market size and relative size of the two economies significantly increase FDI flows, and distance significantly reduces FDI flows. European convergence variables, such as equalisation of financing costs, convergence of government fiscal policy and the similarity of government debt, all increase bilateral FDI flows. In contrast, low labour cost is not an attractive factor of the EU FDI.

Biswas (2002) also found that low wage is not a significant factor in attracting US MNEs, using FDI data from the Bureau of Economic Analysis (BEA) from forty-four countries during the period 1983-1990. Instead, many institutional factors, such as the regime type of the host country, regime duration and property rights index, are significant, suggesting the importance of a healthy institutional environment in attracting US FDI. Sethi et al. (2003) studied the changing trends in the US FDI into the Western European and Asian regions over the period 1981-2000. During 1981-1982, their results show that US FDI has gone to Western Europe because of its high political and economic stability and high 
GNP. Cultural proximity to the USA is a strong determinant, with cultural distance being negative and highly significant. However, the data between 1981 and 2000 show that US FDI was attracted by low GNP countries and that the negative impact of cultural distance on US FDI diminished. This historical pattern indicates that once US MNEs confronted the declining profits in Western Europe, the resulting cost reduction pressures impelled them to start making much more efficiency-seeking FDI into Asia, although Asian countries do not provide the best mix of the traditional determinants of FDI. Moreover, the high-wage differential between West Europe and Asia is the most significant factor contributing to the restructure of US FDI during 1981-2000, suggesting that low labour costs do matter, but only in the long-term and within countries with heterogeneous labor costs or quality.

As a result of the transition of several Central and Eastern European and the Chinese economies from communism to a market-based economic system, there has been growing attention paid to the impact of the country-specific risks and institutional and political environments on FDI inflows. Bevan and Estrin (2004) reported that, based on a panel data of bilateral flows of FDI from Western countries in eleven Central and Eastern European (CEE) countries, key announcements on progress in EU accession had a significant and positive impact on FDI inflows, but FDI flows to transition economies are not influenced significantly by market evaluations of country-specific risk. Brada et al. (2006) investigated the impact of political factors on FDI flows into seven transition economies in Europe from 1993 to 2001 . They found that the initial cumulative inflation rate, the cumulative GDP decline, the share of the private sector in GDP, and change in the unemployment rate significantly reduced FDI inflows. The index of infrastructure reform of a country, lending minus deposits, and change in current account (percentage of GDP) increased FDI inflows, and therefore confirmed the benefits resulting from reform policies.

Egger and Winner (2006) studied the impact of corruption in a panel of bilateral outward FDI stocks of twenty-one OECD countries in fifty-nine OECD economies between 1983 and 1999. They found a negative impact of corruption on FDI. In addition, corruption is important for intra-OECD FDI but not for extra-OECD FDI and overall the impact of 
corruption has declined over years, suggesting that other factors have become relatively more important than corruption. Similarly, Aizenman and Spiegel (2006) used the index of corruption based on Davoodi and Tanzi (1997) to indicate the level of institutional inefficiency in ninety-seven countries from 1990 to 1999 and found it significantly negatively related to the ratio of inward FDI to gross fixed capital formation, confirming their hypothesis that MNEs are more sensitive to institutional inefficiency in the host country than domestic firms. Similarly, despite the overall phenomenal FDI into China, Hsiao and Hsiao (2004) found that from 1986 to 2002 the political deficiency and potential risks of China have showed statistically negative impacts on investors' decisions on entering China.

\subsection{FDI from developing countries}

FDI from developing nations is still in its infancy but has become increasingly important (WIR, 2006). Most FDI from developing countries goes to other developing countries and is called south-south FDI (Aykut and Ratha 2004; Gelb 2005). Market-access and resource-access are the most important drivers of south-south FDI. Another noteworthy phenomenon is that many developing countries are aggressively engaged in cross-border mergers and acquisitions as a strategy to enter overseas markets. However, due to its relatively new prevalence and limited data availability, there is a lack of systematic study on the determinants of FDI from developing countries. Wu and Chen (2001) discussed China's outward FDI. They suggested in the 1980s, the majority of Chinese enterprises involved in transnational operations are state-owned enterprises, and the government maintains extensive controls over the market operations of these enterprises to serve its political and diplomatic motivations. However, since 1991 more and more national and regional business groups have begun to go overseas with trade and market related motivations. No statistical analysis is provided regarding the locational determinants of Chinese FDI in their research. Buckley et al. (2007) provided one of the first statistical attempts to analyse the determinants of Chinese outward FDI. The most important contribution of the research is that it shows determinants of Chinese FDI vary over different time periods. For example, while political risk (lower risk scores) of the host country is found to be positively related to Chinese investment flows between 1982 and 
1991, this result disappears in the time period of 1992 to 2001. The impact of geographic proximity to China is significant and negative for the period between 1984 and 1991, but not for the period of 1992 to 2001. They also found that Chinese FDI is attracted by market size of OECD countries, but attracted to non-OECD countries which have strong trade relations with China.

\section{Hypothesis Development}

Since the empirical literature has suggested that FDI responds to a wide rage of stimuli, we decide to include the most widely acknowledged factors in our investigation to keep the econometric analysis both manageable and representative. We present our hypotheses in this section with theoretical and/or empirical justification of their inclusion. Our first observation is the impact of market size. The reason for its inclusion is twofold. First, market access is the most widely acknowledged motivation of FDI, and empirically has obtained the most unanimous confirmation (Chakrabarti 2001). Secondly, anecdotal information has suggested that Chinese and Indian FDI is market motivated. For example, there has been excessive competition, thinning margins and overcapacity within many industries in China, which have spurred companies to invest abroad with a view to creating an overseas-based platform from which to gain access to local markets (Global Insight 2006). WIR (2006) suggested that one of the most important motivations for Indian MNEs is market access. As a result, we suggest:

H1: China's and India's FDI is positively related to host market size.

Since we consider that Chinese and Indian FDI is market driven, market openness has to be considered alongside market size. Although the importance of market openness has been established based on empirical studies of developed economies, we suggest this is also relevant to Chinese and Indian FDI. Internationalization is a challenging process, full of risks and uncertainties. Cumbersome administrative process and unnecessary rigid regulations in the host country can make the process even more difficult. As such, MNEs, especially those from developing countries which lack international experience, will favour countries with open and friendly business environment. According to a recent survey conducted by Asia Pacific Foundation of Canada (2005), market related factors, 
such as membership in a regional free trade, and use of target country as base for exports to third country, have been listed as driving forces of current Chinese FDI. UNCTAD (2004) also discussed the importance of accessible markets for Indian investors' location choice. It becomes clear that MNEs may engage into different types of cross-border activities to support and develop their global operations. Countries with many restrictions on these activities may cause for concern among multinationals and therefore reduce FDI inflows as a result. Market openness has been found to be important for FDI flows in numerous studies, such as Kravis and Lipsey (1982), Pistoresi (2000), Aizenman and Spiegel (2006) and Buch et al. (2005). As a result, we suggest,

H2: China's and India's FDI is positively related to the openness of the host country.

The third area we examine is access to natural resources. This has been an important conventional factor explaining FDI. Moreover, China and India are the two biggest and fastest developing countries in the world; the need to secure access to overseas natural resources, such as energy and raw materials, is becoming increasingly important. Tan (1999) reported some cases of Chinese firms investing in Thailand for some locationspecific natural resources. The importance of accessing overseas natural resources has also attracted government attention in China. Lunding (2006) reported that the Chinese authorities have been aggressively courting the governments of host states by strengthening bilateral trade relations, awarding aid and providing much-needed transport and communications infrastructure to enable Chinese firms to access the strategically important raw materials. Securing natural resources is also becoming an important driver for Indian outward FDI (WIR 2006). We therefore suggest the following hypothesis:

H3: China's and India's FDI is positively related to the natural resource endowment of the host country.

The relation between trade and FDI has received renewed attention (Blonigen 2001; 2005). Replacing the traditional view that FDI and trade are substitutes, recent studies have revealed more complex relations. A prior trading relationship between a host country and an investing country can increase follow-up FDI. This is particularly relevant when multinationals want to serve the overseas market directly after previous exporting experience. In addition, FDI may reduce imports from a host country if it can result in the 
securing of needed materials and production inputs directly. The complex relationships have been investigated in earlier studies, such as Fedderke and Romm (2006), Buckley et al. (2007), and Bevan and Estrin (2004). As such, we suggest,

H4: China's and India's FDI is positively related to trade relations with the host country.

The exchange rate has a most important link with economic policy and international competitiveness, yet the effect of the exchange rate on FDI is one of the most controversial among the less conventional factors of FDI. Feenstra (1998) suggested that host currency appreciation reduces the wealth of foreign investors, and therefore will reduce investment. In contrast, host currency depreciation could not only attract more FDI directly by lowering asset prices, but also may gain more benefits to subsidiaries exporting from the host to overseas market. However, De Mello (1997) and Pain and Welsum (2003) argued that host currency appreciation may well stimulate inward investment that wishes to sell within host markets. Cushman (1984) suggested that host currency depreciation can make purchasing intermediate goods from a home country more expensive and subsequently reduce import-needed FDI. Theoretically, there are multiple channels wherein different impacts of exchange rates on FDI could take place, leaving no single prediction on FDI (Pain and Welsum 2003). Empirically, WIR (2006) has pointed out that the rise in its foreign currency reserves accelerated the growth of outward FDI from China, although there is a significant decline in the outward FDI conducted by Asian NIEs in 2005. While the Chinese RMB has been pegged to US dollars, it seems reasonable to expect that the exchange rate of host countries will have an impact on China's FDI flows. The possible positive link between an appreciating Chinese RMB (or depreciating host currency) and its outbound FDI could be well strengthened by the fact that a significant portion of Chinese FDI is government funded or assisted. For example, selected State owned enterprises (SOEs) and private owned enterprises (POEs) in China were given favourable financing in the form of credit lines, low interest loans, and foreign exchange (IBM Business Consulting 2006). It is likely that these privileged Chinese enterprises induce the government to rigorously employ the benign opportunity provided by a strong RMB, and therefore accelerate the positive connection between favourable exchange rates and their overseas investment. 
Indian foreign exchange reserves have also been unprecedentedly high, reaching US\$ 102 billion in 2003, US\$ 131 billion in 2004 and US\$ 166 billion in 2005, as reported by the IMF. In fact, its exchange reserve has exceeded that of USA, France, Russia and Germany. The strong Rupee may encourage Indian firms to invest abroad because it increases their purchasing power. As such, the exchange rate should also be a matter to consider for Indian MNEs' overseas expansion; albeit the accelerating impact of government intervention may be absent. Therefore we suggest two hypotheses concerning the impact of exchange rate.

H5a: China's and India's FDI is positively related to host currency depreciation.

H5b: The positive association of depreciating host currency (appreciating home currency) is stronger on China's FDI than on India's FDI.

Recently, scholars have theoretically and empirically suggested that a wide range of host characteristics which reflect the 'nature' of the host environment affect FDI. For example, Baniak et al. (2003) theoretically suggested there is an adverse selection effect from macroeconomic and institutional inefficiency of the host country, where investors aiming for the long-term development in the host country will be deterred, but those only for short-term rents from selling-buying assets are promoted. Alvaro (2006) found that corruption results in relatively lower FDI from countries that have signed the Organisation for Economic Cooperation and Development (OECD) Convention on Combating Bribery of Foreign Public Officials in International Business Transactions, but relatively higher FDI from countries with high levels of corruption. Although there are certain institutional differences between China and India, it is suggested that their FDI would be negatively related to the host institutional inefficiency. As such, we propose:

H6: China's and India's FDI is positively related to a better institutional environment of the host country. .

Finally, the impact of geographical distance on FDI has been studied extensively in the empirical literature. The common view is that distance makes cross-border coordination expensive and therefore tends to reduce FDI. However, a positive effect might also exist if the FDI overcomes export costs. A significantly negative impact of distance is found in Aizenman and Spiegel (2006), Bevan and Estrin (2004), Buch et al. (2005), Janicki et al. 
(2005) and Hsiao and Hsiao (2004). A negative yet insignificant impact appears in Buckley et al. (2007), Wei (2005) and Carr et al. (2001). In addition, earlier research by Gao (2005) found distance is a greater barrier to FDI from four Asian economies (Singapore, Taiwan, Malaysia and Thailand) compared to FDI from OECD countries. Since China has a strong cultural linkage with these countries, investors may have a similar reaction to distance and hence FDI from China may show similar pattern. India, although also an Asian country, has a rather distinctive cultural attribute. Its century long colonization by the United Kingdom has greatly influenced its social, political and cultural system. So it might not share the attributes of the typical Asian countries in their outward investment. Hence, we propose:

H7a: Distance is negatively related to China's and India's FDI.

H7b: The negative impact of distance is stronger for China's FDI than for India's FDI.

\section{Data and variable measurement}

This section provides a discussion of measuring the dependent and independent variables as well as the data structure.

\subsection{Data}

The database comprises various sources. First, we include the top thirty destinations for Chinese (1999-2002) and Indian (2001-2004) FDI, derived from the UN database. To improve the year coverage, we amended our database by adding Chinese and Indian FDI into ASEAN countries (1995-2004), which is drawn from the ASEAN Statistics Yearbook 2005. China and India's FDI into Japan (1989-2005) and the United States (1980-2005) are derived from the Ministry of Finance of Japan and Bureau of Economic Analysis (BEA), respectively. The dependent variable is the annual bilateral FDI flows from China and India to the sampled host countries. The nature of our panel data is unbalanced in the sense that from 1980 to 2005 some countries have full data (i.e., 26 observations) and some have incomplete data (see Table 2 for sample composition). Additionally, we replaced the missing observations for some independent variables (i.e., LNEXPORT and variables related to legal environment) with their average values for the period. 
(INSERT TABLE 2 ABOUT HERE)

\subsection{Dependent variable (FDI)}

The dependent variable is the aggregate annual flow of foreign direct investment (millions US\$) by Chinese and Indian firms.

\subsection{Independent variables}

We measure market size by a few different indicators. The first (LNGDP) is the natural logarithm of GDP in billion US\$. We also use the natural logarithm of GDP per capita (GDPPC) in 1000 US\$, and GDP growth (GDPGW) as alternatives to indicate market size. The data are derived from the World Bank's World Development Indicators (April 2005). For a host country's openness, we use two measures. The first is the natural logarithm of inward FDI stock (LNFDI-STOCK) in million US\$, with Chinese and Indian FDI excluded to avoid bias. The second proxy is perhaps the most conventional one, namely, the ratio of the sum of imports and exports to the country's GDP (MX/GDP). It is acknowledged that openness is a multi-dimensional concept. We decide to use the two conventional measures to be consistent with the majority of existing studies. The data are derived from World Development Indicators (WDI) and UNCTAD's online FDI database.

To proxy for the natural resources endowment of a country, we employ the percentage of ores and metals exports to total merchandise exports by country (RESOURCE), as reported by the World Bank in its World Development Indicators. Trade intensity is proxied by the natural logarithm of the value of a host country's exports to (LNEXPORT), and imports from (LNIMPORT), China and India respectively, expressed in historical million US dollars, as reported by the Chinese National Bureau of Statistics in the China Statistical Yearbook and the Export and Import Bank of Indian Department of Commerce. It is noted that this variable differs from the second proxy of 'openness' although both measurement involves trade. It is a pair-specific variable, whereas 'openness' is a host country specific variable. Exchange rate (EXCHANGE) uses the first month's exchange rate of the local currency to US dollars for the year outward FDI is conducted. The data source is the IMF. We use bureaucracy quality, corruption and 
political risk to indicate institutional inefficiency. The data are gathered from the International Country Risk Guide published by the PRS Group, a standard index used in this type of work. Bureaucracy quality index (BUREAU) is based on four points. High points are given to countries where the bureaucracy has the strength and expertise to govern without drastic changes in policy or interruptions in government services. The Corruption index (CORRUPTION) is based on six points, with higher scores indicating lower corruption. The Political Risk index (POLRISK) is based on 100 points, with higher scores indicating lower risk. Geographic distance is measured by the natural logarithm of air miles between the capital cities of China/India and the host country.

\subsection{Other variables}

We include three more variables to supplement the main model. The first is the inflation rate (INFLATION) of the host country. This variable can reflect the macroeconomic stability of the host environment. A more stable macroeconomic situation should encourage FDI, whereas a high inflation rate may reflect economic and financial instability in the host country and therefore deter FDI flows. It is also included in earlier empirical studies, such as Buckley et al. (2007). The annual inflation rate of the host country was obtained from the World Economic Outlook Database of the IMF. The second is the interest rate of the host country. It should be noted that one should avoid including both inflation and interest rate variables in the same model as they are generally alternatives to each other. The interest rate of the host country was obtained from the World Economic Outlook Database of the IMF. Finally, we also include corporate tax in the model. The importance of this factor is that it directly relates to the profitability of foreign direct investment. The orthodox assumption of profit maximisation leads us to propose that a high corporate tax rate would deter FDI, unless the motives of investors deviate from profit maximisation. Data on corporate tax rates is from the Institute of Fiscal Studies (Klemm, 2005). It is noted that for all non-ratio variables (e.g. FDI, GDP) we used producer price index (PPI) to eliminate the impact of inflation. Hence the figures are in the base-year prices. 


\section{Results}

\subsection{Descriptive statistics}

Table 3 reports the descriptive statistics for China (Panel A), for India (Panel B) and for the host countries (Panel C). On one hand, the value of standard deviation, kurtosis and skewness of China's FDI is systematically smaller than that of India. This implies that China's FDI has a more even distribution throughout the years than India's FDI. On the other hand, average Indian outward FDI is higher than China's outward FDI in the sample. The amount of exports from and imports to host countries is higher for China than to India. The mean and median of geographical distance for China's and India's panel are similar, but the standard deviation, kurtosis and skewness of India's sample is much smaller than that of China's panel. The remaining variables, namely bureaucratic quality, corruption, political risk and tax rate are highly similar for China and India's panels. However, the mean and median of interest rate and tax rate are higher for Chinese data than that of India's.

\subsection{Univariate analysis}

Table 4 reports the correlation matrix for the variables used in the analysis. In Panel A (China), the variable of FDI has a significant correlation with bilateral trade between China and host countries, bureaucracy quality, corruption and political risk. Other variables also contain the correct signs, but without statistical significance. One exception to our expectations is GDP growth, which has a negative correlation with FDI. In Panel B (India), FDI has a significant correlation with the quality of bureaucracy and corporate tax rate of host countries, albeit the former has an unexpected positive correlation. The remaining variables all attain correct signs but again without statistical significance.

\subsection{Multivariate analysis}

\subsubsection{Regressions using pooled data}

Table 5 reports the regression results for the pooled sample using fixed-effects estimates. We used the Hausman test to choose between random effects and fixed effects. In all cases (tables 5 and 6) and for the non-reported regression results, the Hausman p-values were lower than 0.05 , thus rejecting the null hypothesis that the coefficients estimated by 
random effects are the same as the ones based on fixed effects method. We conclude that the correct estimation method is fixed effects. Furthermore, although the fixed effects method controls for unobserved country-specific heterogeneity, it does not attempt to control for endogeneity. To partially account for this problem, we lagged by one period the apparently endogenous trade measures. We also dropped GDP per capita since it never attained significance in the preliminary analysis.

The results show some sensitivity of the results according to different variables included. In Model 1, GDP obtained a statistically significant result with a positive sign, suggesting that both Chinese and Indian FDI are market seeking. This supports hypothesis 1. Market openness, as indicated by FDI stock, is also a positive and significant estimator. This suggests that Chinese and Indian FDI tend to be attracted to countries which have been generally open to inward FDI. Thus our second hypothesis is also supported. Resource intensity is not a significant factor. This finding contradicts our third hypothesis. This may be a consequence of the sample composition, since resource-rich countries, such as African countries, have a very limited presence in the sample. Alternatively, it may be that the resource-seeking is an industry specific attraction for FDI, but not so strongly as to affect aggregate FDI which contains a broad range of industries. Contrary to our fourth hypothesis, export between the host country and China/India is also an insignificant factor in Model 1. However, it is too early to judge that trade relations have nothing to do with FDI outflows from China and India since export is only one side of the coin. We will examine the impact of imports on FDI in model 5, allowing us to fully assess the impact of trade relations on FDI. Furthermore, exchange rates do not exert any significant role on outward FDI. This surprising result may reflect the mitigating effect of the 'wealth effect' and 'declining profit margin' effect of the exchange rate in this pooled sample.

The coefficient on political risk is significantly positive, suggesting that the higher scores the host country has (the lower risk it is), the more FDI it attracts. This confirms our hypothesis that a sound institutional environment is conducive to international investment and therefore tends to attract more FDI from China and India. The coefficient on geographical distance is significantly negative, which indicates that outward FDI is deterred by geographical distance that makes cross-border coordination and monitoring 
difficult. Hence, hypothesis 7a is supported. The association of inflation with outward FDI, on the other hand, is found statistically insignificant. However, the corporate tax rate carries a significantly negative coefficient, suggesting China's / India's FDI is deterred by high corporate tax.

Finally, we examine the impacts of a few dummy and interactive variables. The significantly positive China dummy coefficient suggests that, controlling for a series of factors, outward Chinese FDI exceeds the Indian counterpart. Equally interesting, we find that the OECD dummy is significantly negative, suggesting overall FDI tends to decrease when the host country is an OECD member. The interactive effect of the exchange rate and the China dummy is insignificant, implying that Chinese outward FDI does not react to exchange rates differently compared to Indian FDI. However, the interaction between distance and the China dummy is negative and significant at the $1 \%$ level. This confirms our hypothesis that distance is a greater barrier to FDI from China, a similar impact experienced by other Asian countries, such as Singapore and Malaysia.

As an alternative indicator of institutional environment, we replace political risk with bureaucratic quality in Model 2. The model obtains results highly similar to those of Model 1, but bureaucratic quality does not reach statistical significance. The other difference between Models 1 and 2 is that we replaced inflation with the interest rate, which obtained qualitatively unchanged findings. Similarly, Model 3 produced similar results as those of Model 1, except that we replaced political risk with corruption. The significance of the corruption estimator is in line with our hypothesis (recall that higher scores of corruption indicate lower corruption levels). The findings based on alternative variables that proxy institutional environment support our hypothesis that both Chinese and Indian FDI are attracted to a sound host institutional environment. In Model 3, we also use an alternative openness measure, the sum of exports and imports of the host country divided by its GDP, and we find that the significance level of the openness coefficient improves to $1 \%$. This result fortifies the notion that both China's and India's FDI are attracted by open economies. 
In Model 4, we test the alternative variable of market potential by replacing GDP with GDP growth. We find that growth rate negatively and significantly impacts outward FDI. This indicates that the Chinese and Indian FDI is demoted by rapid economic growth of the host country. One explanation of this apparently counter-intuitive result is that Chinese and Indian FDI is more attracted by established economies, which have passed the phase of rapid economic growth and may in some cases even experience a slight economic recession. In fact, a number of developed economics had experienced various degrees of recession between the 1990s and early 2000s, such as Japan (started early 1990s and the recession is still ongoing), Australia, and Germany. Second, ASEAN countries constitute a significant part of our sample. But even the economic boom experienced by some ASEAN countries had ceased in 1997 due to the widespread Asian financial crisis. In addition, our result shares some resemblance with Nigh (1985) in which host GDP growth also has a negative, albeit weak, impact on FDI outflows from the United States.

To focus on the inverse relation between outward FDI and GDP growth, we add an interaction variable of GDPGW*GROWTH DUMMY in Model 4, where Growth Dummy is 1 if GDP growth is negative ( 0 otherwise). The significantly positive coefficient on the interaction variable suggests that the negative relation between outward FDI and GDP growth becomes 'less negative' when the GDP growth is negative. This is not only surprising but also it makes the reconciliation between the results of GDP growth and the corresponding interaction variable more difficult. This puzzling result may echo Chakrabarti's comment (2001) that GDP growth is one of the controversial variables in studying FDI. Indeed, previous studies have not reached conclusive result regarding the impact of GDP growth (Nigh 1985; Tsai 1994; Billington 1999).

In Model 5, we replace exports with imports and find that, in contrast to exports, imports into the host country from China/India are an important estimator of FDI. This can be interpreted as both China's and India's FDI being motivated by further market establishment in the host country following up its exporting (to the host country, i.e. our import variable) activities. With accumulated learning experience from export, undertaking direct investment becomes an evolving strategy for Chinese and Indian firms 
to further explore the overseas market. Hence, hypothesis 4 attains some empirical support. Finally, considering the data are unbalanced and there is no pre-1995 data except for the U.S., we dropped the US data in Model 6 to overcome the possibility that the US data may have biased our results. We obtained qualitative unchanged results in Model 6 (except the tax variable), suggesting this is not a serious problem with the data.

\subsubsection{Regressions using data for each country}

Table 6 reports the separate regression results for China's and India's panel data, from which we observe important similarities and differences. We omitted a few variables, such as bureaucratic quality and corruption, because they attained less statistically satisfactory results than their alternatives.

First, we find that GDP is a significant positive estimator of both China's and India's FDI. This suggests that FDI from the two countries is market seeking. However, the impact of host market size has a greater impact on China's FDI, as shown by the higher magnitude and statistical significance in China's case. Similar to the results in Table 5, GDP annual growth rate is found to be a significantly negative estimator of China's and India's FDI. The negative impact of GDP growth is even stronger in China's case.

Market openness, measured by the sum of imports and exports divided by host country's GDP, achieves marginal significance in China's sample, except in Model 3, but no statistical significance in India's sample. This could be a consequence of the heterogeneous composition of China's and India's FDI. If the outward FDI is more vertical, then it tends to be more attracted by open trade regimes which facilitate import and export activities of FDI. In contrast, horizontal FDI aims for the host market, which renders it less important whether or not the host economy is open to international trade. As such, we conjecture that China's FDI could be more vertical, relative to the Indian case, and therefore is more attracted to open trade regimes. However, empirically differentiating vertical FDI from horizontal is difficult. The current practice (e.g. Aizenman and Marion 2004; Carr et al 2001) is to use local sales by foreign invested firms as the indicator of horizontal FDI and export as that of vertical FDI. We are not able to investigate them empirically because of data unavailability. 
Resource intensity is found to be an insignificant factor with a counter-intuitive negative sign. As mentioned earlier, it may be that the resource-seeking is an industry specific attraction, but not so strong as to show up in aggregate FDI data which contains multiple industries.

The host country's exports to China/India are not a significant variable. In contrast, the host country's imports from India are found to be positive and significantly related to India FDI, but this effect appears only in Model 3 for China's case. Taking the trade related factors collectively, we suggest that Indian FDI tends to flow to countries where India has had extensive export activities. Follow-up FDI may be used to further develop their establishment in the host market. But this impact is less significant for China's case. This may be because China's FDI is less horizontal than that of India. This is consistent with our conjecture concerning the result on market openness.

Generally, the finding on India's FDI is in line with Vernon's (1966) argument that firms primarily produce in and export from the domestic market. Accumulated international experience through exporting and an increasingly saturated domestic market will motivate them to undertake FDI to explore and serve overseas markets directly.

We find a contrasting result of the impact of the exchange rate on China's and India's FDI. While host country currency depreciation is found to carry a significant and positive sign on China's FDI, this is not the case for India's FDI. Two explanations may decipher this divergence. First, China's FDI is stimulated by the 'wealth effect' brought about by the depreciated host currency, and is simply less concerned about the reduced profit margin associated with depreciated currency. India's sample suggests that the 'wealth effect' and reduced profit margin effect may have offset each other and thus led to an insignificant result. This also hints that India's FDI may be more cautious and not attracted by short-term expansion, but rather long-term market viability. Second, a possible heterogeneous composition of Chinese and Indian FDI may have contributed to the result. We have already speculated that Chinese FDI is more vertical whereas Indian FDI is more horizontal. Vertical FDI will increase when the host currency depreciates 
because it leads to a combined benefit of reduced initial investment costs and lower prices for export products. For horizontal FDI, although a depreciated host currency equally reduces initial investment costs, it will also bring down the profit margin. The statistical results do not fully confirm hypotheses $5 \mathrm{a}$ and $5 \mathrm{~b}$, but they do unveil a quite distinctive reaction of China's FDI to exchange rate.

A recent publication studying Chinese, Indian and South African multinationals in subSaharan Africa (SSA) finds evidence that lends some support to our interpretation (Henley et al 2008). For example, it is found that Chinese firms are expanding their operations very rapidly compared to their Indian peers, although they achieve much lower sales per employee. More interestingly, the research also discovers that Chinese firms are significantly more export-oriented than investors from India, and "even recently arrived Chinese firms are setting up export platforms in East Africa incentivized by third country trade regimes" (p.13). As such, we have more confidence in suggesting that both the vertical nature of Chinese FDI and government intervention have contributed to the impact of exchange rates on the location choices of Chinese investors. However, these two factors are absent in the Indian case.

China's and India's samples also attained divergent results on political risk. In China's sample, political risk of the host country obtains a significantly positive result. Since high scores of political risk indicate low risk of the host country, this result reveals that China's FDI is attracted by countries with good institutional environment, thus confirming our hypothesis. However, this variable has no significant impact on India's FDI.

We also found a divergent impact of geographical distance on China's and India's FDI. While it has a significantly negative impact on China's FDI, distance does not significantly influence outward Indian FDI. Our result is similar to those of Gao (2005) in which distance is found to be a greater barrier to FDI from four Asian economies (Singapore, Taiwan, Malaysia and Thailand) compared to FDI from OECD. This somewhat confirms our conjecture that China has an inherent cultural linkage with these four countries and that entrepreneurs in these countries share a similar mindset in their 
going-global strategies. In contrast, India represents a distinctive culture from East Asia and thus does not share this feature. Theoretically, the impact of geographical distance is ambiguous in most FDI frameworks, such as the knowledge-capital model, where it is proposed to have a negative impact on vertical FDI, but less so on horizontal FDI. In more extreme cases, geographical distance could promote market-seeking FDI because FDI saves the transportation costs that exporters have to bear in serving an overseas market. As a result, the other causes for the contrasting impact of geographical distance on China's and India's FDI could be, again, the heterogeneous composition of their aggregated FDI.

Inflation is found to be an insignificant factor for both China's and India's FDI. Another important finding of commonality between India and China is corporate taxation. We found that it has a significant and negative impact on Chinese and Indian FDI. This confirms our proposition that a host's high corporate taxation deters inward FDI.

We also test whether English language proves attractive to Chinese and Indian FDI. We find that Chinese FDI is positively related to countries with English as official language. This probably indicates that Chinese investors pursue English-speaking countries because of their dominant position in the world economy. Information on these countries is abundant and easier to translate. In addition, many Asian countries (or regions) which have cultural linkage with China, such as Hong Kong, Singapore, and Malaysia, use English as first or second official language. This could have increased the positive impact of English speaking on Chinese FDI. While this result is interesting but not counterintuitive, the insignificant result of this variable on Indian FDI is puzzling. One possible explanation is that although India is an English speaking country, it has a vast number of dialects. This could reduce the importance of English as an attractor to its investment. More importantly, its complex colony history by Western European countries, such as the Portuguese, Dutch, French, and Danish, apart from the UK, perhaps has enabled it to have close relations with some non-English speaking countries, thus reducing the dependence on English as communication language. 
China continues its distinction from India in the OECD dummy variable, which is significantly negative for the former and insignificant for the latter. Since 28 out of 30 OCED countries are from North America and Europe, this result suggests that China's FDI is constrained by its geographical scope, whereas India's is not. Finally, as in Table 5 , the interaction between growth rate and growth dummy has attained a statistically significant result for both China and India.

Our results are in agreement with findings from a few previous studies, such as the impact of host GDP, resource endowment and inflation rate, in Buckley et al. (2007) and the divergent characteristics of Chinese FDI compared to that of Indian as shown in Henley et al. (2008). However, one striking difference between our results and those in Buckley et al. (2007) is that they concluded that Chinese FDI is attracted rather than deterred by political risk (p.513). However, this could be an imprecise interpretation on their part, because a closer look at the data in Buckley et al. (2007) shows that higher values indicate greater stability (hence lower risk). As a result, a significant and positive association between this variable and Chinese FDI, as shown in Table 6 (p. 512) of their paper, ought to be interpreted as suggesting that China's FDI is attracted to nations of higher political stability. If this is indeed a misinterpretation, then our result is consistent with theirs. Since, to our best knowledge, there is no statistical investigation of India's outbound FDI, we have little to compare for India's case.

\section{Summary and conclusion}

This study attempts to investigate the locational determinants of Chinese and Indian outward FDI. The traditional FDI framework has suggested a host of factors that are empirically and theoretically important in explaining the flows of FDI. We test the framework and find some important commonalities shared by the two countries. To be more specific, we found that Chinese and Indian FDI are attracted to countries with large market size, high volumes of import from China/India, and low corporate tax rates. The host country GDP growth is found to deter Chinese and Indian FDI. 
China and India also demonstrate important differences in their FDI outflows. While Chinese FDI is promoted by open economic regimes, depreciated host currency, and better institutional environment, these factors are not important for Indian FDI. In addition, geographic distance significantly reduces Chinese FDI outflows but such effect is absent on Indian FDI. More interestingly, Chinese FDI is also drawn to Englishspeaking countries but deterred by OECD membership, and yet none of these is important for Indian FDI.

We discuss policy implications of our empirical results. First, the divergent result of exchange rate suggests that India's FDI aims for long-term profit viability, while China's FDI looks for rapid overseas expansion unless it is truly vertical weighted. Leveraging the advantage of a strong RMB is recommendable for vertical investment, but for nonvertical FDI, caution is warranted because rapid international expansion and the longterm profit viability need to be properly balanced to maximize the benefits and minimize the costs of internationalization. Second, regarding the negative impact of OECD and distance on China's FDI, it may take time for Chinese investors to be more comfortable with OECD countries and countries that are physically far away from China. However, these countries have to be taken into account if Chinese investors want to have a truly international presence. Third, the non-significant impact of political risk on Indian FDI is rather unusual. It seems that a combination of historical, cultural and political reasons may have driven this result. Unless Indian FDI has competitive advantage in mitigating negative impact of political risk, caution needs to be taken in estimating their ability to cope with inefficient institutional systems. This is particularly imperative for multinationals aiming for emerging markets.

One interesting finding of our research is on GDP growth. FDI from China and India reacts negatively to GDP growth, making it rather counter-cyclical. Hence, it can contribute to macroeconomic stabilization in the host country. Another relevant issue may be the composition of China's and India's FDI. Some factors (e.g. exchange rate and distance) indicate that China's FDI is more likely to be vertically weighted. While there is no clear-cut argument of which type of FDI is superior, it is a consensus that vertical FDI is more footloose than horizontal FDI. In order to promote a positive impact of vertical 
FDI, host countries need to encourage wide cooperation between local stakeholders and Chinese investors to enhance their embeddedness in the local economy. Equally, a few results collectively suggest that India's FDI is more horizontal. Although we are not in a position to fully assess the exact impact of such FDI, what is certain is that horizontal FDI tends to be more integrated with the local economy.

This study has contributed to our understanding of locational determinants of China's and India's FDI, but one should acknowledge some limitations. First, our results may suffer from small sample bias. Future work can add more countries from Africa and Western Europe to balance the sample composition. This will make the statistical analysis more robust and reliable. Secondly, as institutional environment is a complex concept to analyse, it is desirable to decompose this factor into different components to have a finer analysis of its impact on FDI decisions. Thirdly, our research has generated some rather unusual results, such as the impact of English speaking on India's FDI, and the impact of GDP growth. These indorse further empirical investigation with better data coverage. 


\section{References}

Aizenman, Joshua and Nancy Marion (2004), "The merits of horizontal versus vertical FDI in the presence of uncertainty," Journal of International Economics, 62(1), 125-148.

Aizenman, Joshua and Mark Spiegel (2006), "Institutional Efficiency, Monitoring Costs and the Investment Share of FDI," Review of International Economics, 14(4), 683-697,

Alvaro, Cuervo-Cazurra (2006), "Who cares about corruption?" Journal of International Business Studies, 37(6), 807-822.

Asia Pacific Foundation of Canada (2005), "China Goes Global: A Survey of Chinese Companies Outward Direct Investment Intentions," China Council for the Promotion of International Trade.

Aykut, Dick, and Dilip Ratha (2004), "South-South FDI flows: How Big Are They?" Transnational Corporations, 13, 149-176.

Baniak, Andrzek, Jacek Cukrowski, and Jan Herczynski (2003), "On the determinants of foreign direct investment in Transition Economics," Problems of Economic Transition, 48(2), 6-28.

Battat, Joseph and Aykut Dilek (2005), "Southern Multinationals: A Rising Force in the World Economy," 9/10, (November), Mumbai India, FIAS.

Bevan, Alan and Saul Estrin (2004), "The determinants of foreign direct investment into European transition economies," Journal of Comparative Economics, 32 (4), 775-787.

Billington, Nicholas (1999), "The Location of Foreign Direct Investment: An Empirical Analysis," Applied Economics, 31, 65-76.

Biswas, Rita (2002), "Determinants of Foreign Direct Investment," Review of Development Economics, 6(3), 492-504.

Blonigen, Bruce (2001), "In Search of Substitution Between Foreign Production and Exports," Journal of International Economics, 53(1), 81-104.

Blonigen, Bruce (2005), "A Review of the Empirical Literature on FDI Determinants," NBER Working Paper.

Brada, Josef, Ali Kutan and Taner Yigit (2006), "The effects of transition and political instability on foreign direct investment inflows," Economics of Transition, 14(4), 649680.

Buch, Claudia, Jörn Kleinert, Alexander Lipponer, and Toubal Farid (2005), "Determinants and effects of foreign direct investment: evidence from German firm-level data," Economic Policy, 51-110. 
Buckley, Peter, Jeremy Clegg, Adam Cross, Xin Liu, Hinrich Voss, and Ping Zheng (2007), "The determinants of Chinese outward foreign direct investment," Journal of International Business Studies, 38, 499-518.

Carr, David, James Markusen and Keith Maskus (2001), "Estimating the KnowledgeCapital Model of the Multinational Enterprises," The American Economic Review, (June), 693-708.

Chakrabarti, Avik (2001), "The determinants of foreign direct investment: sensitivity analyses of cross-country regressions," KYKLOS, 54(1), 89-114.

Clegg, Jeremy and Susan Scott-Green (1999), "The Determinants of New FDI Capital Flows into the EC: A Statistical Comparison of the USA and Japan," Journal of Common Market Studies, 37(4), 597-616.

Cushman, David (1984), "Real exchange rate risk, expectations, and the level of direct investment," The Review of Economics and Statistics, 297-308.

Davoodi, Hamid Reza and Vito Tanzi (1997), "Corruption, Public Investment, and Growth," IMF Working Paper WP,97,139.

De Mello, Luiz, Jr (1997), "Foreign Direct Investment in Developing Countries and Growth: A Selective Survey," Journal of Development Studies, 34(1), 1-34.

Dunning, John (1993), Multinational Enterprises and the Global Economy, Wokingham, Berkshire, Addison Wesley.

Dunning, John (2006), "Towards a new paradigm of development: implications for the determinants of international business activity," Transnational Corporations, 15(1), 173 228.

Egger, Peter and Hannes Winner (2006), "How Corruption Influences Foreign Direct Investment: A Panel Data Study," Economic Development and Cultural Change, 54(2), 459-486.

Fedderke, Johannes and Aylit Romm (2006), "Growth impact and determinants of foreign direct investment into South Africa, 1956-2003," Economic Modeling, 23, 738760.

Feenstra, Robert (1998), "Facts and Fallacies about Foreign Direct Investment," NBER working paper.

Gao, Ting. (2005), "Foreign direct investment from developing Asia: some distinctive features," Economics Letters, 86, 29-35.

Gaston, Noel and Douglas Nelson (2002), "Integration, foreign direct investment and labor markets: microeconomic perspective," The Manchester School, 70(3), 420-459. 
Gelb, Stephen (2005), "South-South Investment: The Case of Africa," In African in the World Economy. The National, Regional and International Challenge Fondad, The Hague, December.

Global Insight (2006), “China: Going Outside, 'Round-tripping and Dollar Diplomacy: An Introduction to Chinese Outward investment," Global Insight Group.

Henley, John, Stefan Kratzsch, Mithat Kulur, and Tamer Tandogan (2008), "Foreign Direct Investment from China, India and South Africa in sub-Saharan Africa: A New or Old Phenomenon?" United Nations University, World Institute for Development Economics Research, Research Paper, No, 2008/24.

Hsiao, Frank and Mei-Chu Hsiao (2004), "The chaotic attractor of foreign direct investment-why China? A panel data analysis," Journal of Asian Economics, 15, 641670.

IBM Business Consulting Services (2006), "Going Global: Prospects and challenges for Chinese companies on the world stage," IBM Institute for Business Value, In association with School of Management, Fudan University.

Janicki, Hubert, Thierry Warin, and Phanindra V. Wunnava (2005), "Endogenous OCA Theory: Using the Gravity Model to Test Mundell's Intuition," Centre for European Studies Working Paper, No, 125.

Klemm, Alexander (2005), “Corporate tax rate data,” Institute of Fiscal Studies, Accessed from http://www.ifs.org.uk/publications.php?publication_id=3210, 08/08/2006

Kravis, Irving and Robert Lipsey (1982), "The Location of Overseas Production and Production for Export by U.S. Multinational Firms," Journal of International Economics, 12, 201-223.

Lunding, Andreas (2006), "Global champions in waiting: perspectives on China's overseas direct investment," Deutche Bank Research, Current Issues: China Special.

Nigh, Douglas (1985), "The Effect of Political Events on United States Direct Foreign Investment: A Pooled Time-series Cross-sectional Analysis," Journal of International Business Studies, 16, 1-17.

Pain, Nigel and Dessiree Van Welsum (2003), "Untying the Gordian Knot: The Multiple Links Between Exchange Rates and Foreign Direct Investment," JCMS, 41(5), 823-846.

Pistoresi, Barbara (2000), "Investmenti diretti esteri e fattori di localizzazione: L'America Latina e il Sud Est asiatico," Rivista di Politica Economica, 90, 27-44.

Sethi, Deepak, Stephen Guisinger, Steven Phelan, and David Berg (2003), "Trends in foreign direct investment flows: a theoretical and empirical analysis," Journal of International Business Studies, 34, 315-326. 
Tan, Rosalina (1999), "Foreign Direct Investment Flows To and From China," PASCN Discussion Paper NO. 99-21, Philippine APEC Study Centre Network.

Tsai, Pan-Long (1994), "Determinants of Foreign Direct Investment and Its Impact on Economic Growth,” Journal of Economic Development, 10, 29-45.

UNCTAD (2004), "India's outward FDI: A Giant Awakening? Investment Issues Analysis Branch," UNCTAD.

Accessed from http://www.unctad.org/sections/dite_iiab/docs/diteiiab20041_en.pdf on 4th February, 2008.

Vernon, Raymond (1966), "International investment and international trade in the product cycle," Quarterly Journal of Economics, 190-20.

Wei, Wenhui (2005), "China and India: Any difference in their FDI performances?" Journal of Asian Economics, 16, 719-736

World Investment Report (2006), "FDI from Developing and Transition Economies: Implications for Development," Geneva, United Nations.

Wu, Hsiu-Ling, and Chein-Hsun Chen (2001), "An assessment of outward foreign direct investment from China's transitional economy," Europe-Asia Studies, 53(8), 1235-1254. 
Table 1 Chinese and Indian outward direct investment of 1981-2004, in US\$

\begin{tabular}{|c|c|c|c|c|c|c|c|c|c|}
\hline & YEAR & 1981 & 1982 & 1983 & 1984 & 1985 & 1986 & 1987 & 1988 \\
\hline \multirow[t]{2}{*}{ China } & FDI outflows & .. & 44 & 93 & 134 & 629 & 450 & 645 & 850 \\
\hline & FDI outward stock & 39.4 & 44 & 137 & 271 & 900 & 1350 & 1995 & 2845 \\
\hline \multirow[t]{2}{*}{ India } & FDI outflows & 2 & 1 & 5 & 4 & 3 & -1 & 5 & 11 \\
\hline & FDI outward stock & 80.1 & 81.071 & 86.07 & 90.07 & 93.07 & 92.071 & 97.071 & 108.07 \\
\hline \multirow{3}{*}{ China } & YEAR & 1989 & 1990 & 1991 & 1992 & 1993 & 1994 & 1995 & 1996 \\
\hline & FDI outflows & 780 & 830 & 913 & 4000 & 4400 & 2000 & 2000 & 2114 \\
\hline & FDI outward stock & 3625 & 4455 & 5368 & 9368 & 13768 & 15768 & 17768 & 19882 \\
\hline \multirow[t]{3}{*}{ India } & FDI outflows & 10 & 6 & -11 & 24 & 0.351 & 82 & 119 & 240 \\
\hline & FDI outward stock & 118.07 & 124 & 113 & 293.9 & 294.2 & 376.2 & 495.2 & 735.24 \\
\hline & YEAR & 1997 & 1998 & 1999 & 2000 & 2001 & 2002 & 2003 & 2004 \\
\hline \multirow[t]{2}{*}{ China } & FDI outflows & 2562.5 & 2633.8 & 1774.3 & 915.78 & 6885.4 & 2518.41 & -152.3 & 1805.05 \\
\hline & FDI outward stock & 22444 & 25078 & 26853 & 27768 & 34653.8 & 37172.2 & 37020 & 38825 \\
\hline \multirow[t]{2}{*}{ India } & FDI outflows & 113 & 47 & 80 & 509 & 1397 & 1107 & 913 & 2222 \\
\hline & FDI outward stock & 564.41 & 705.78 & 1707.3 & 1858.5 & 2615.35 & 4005.35 & 5054.4 & 6592.35 \\
\hline
\end{tabular}


Table 2: Sample composition: country and year coverage

\begin{tabular}{|l|c|c|}
\hline Country & Chinese FDI & Indian FDI \\
\hline Australia & $1999-2002$ & $2001-2004$ \\
\hline Austria & NA & $2001-2004$ \\
\hline Brazil & $1999-2002$ & NA \\
\hline Brunei & $1995-2004$ & $1995-2004$ \\
\hline Cambodia & $1995-2004$ & $1995-2004$ \\
\hline Canada & $1999-2002$ & NA \\
\hline China & NA & $2001-2004$ \\
\hline Egypt & $1999-2002$ & NA \\
\hline Germany & $1999-2002$ & NA \\
\hline Hong Kong & $1999-2002$ & NA \\
\hline Indonesia & $1995-2004$ & $1995-2004$ \\
\hline Iran & NA & $2001-2004$ \\
\hline Ireland & NA & $2001-2004$ \\
\hline Italy & NA & $2001-2004$ \\
\hline Japan & $1989-2004$ & $1989-2004$ \\
\hline Kazakhstan & $1999-2002$ & $2001-2004$ \\
\hline Laos & $1995-2004$ & $1995-2004$ \\
\hline Libya & NA & $2001-2004$ \\
\hline Macao & $1999-2002$ & NA \\
\hline Malaysia & $1995-2004$ & $1995-2004$ \\
\hline Mali & $1999-2002$ & NA \\
\hline Malta & NA & $2001-2004$ \\
\hline Mauritius & NA & $2001-2004$ \\
\hline Mexico & $1999-2002$ & NA \\
\hline Mongolia & $1999-2002$ & NA \\
\hline Morocco & NA & $2001-2004$ \\
\hline Myanmar & $1995-2004$ & $1995-2004$ \\
\hline Nepal & NA & $2001-2004$ \\
\hline Netherlands & NA & $2001-2004$ \\
\hline New Zealand & $1999-2002$ & NA \\
\hline Nigeria & $1999-2002$ & NA \\
\hline Oman & $1999-2002$ & $2001-2004$ \\
\hline Papua New Guinea & $1999-2002$ & NA \\
\hline Peru & $1999-2002$ & NA \\
\hline Philippines & $1995-2004$ & $1995-2004$ \\
\hline Russia & $1999-2002$ & $2001-2004$ \\
\hline Singapore & $1995-2004$ & $1995-2004$ \\
\hline South Africa & $1999-2002$ & NA \\
\hline South Korea & $1999-2002$ & NA \\
\hline Sri Lanka & NA & $2001-2004$ \\
\hline Sudan & NA & $2001-2004$ \\
\hline Tanzania & NA \\
\hline Thailand & India, respectively. \\
\hline UK & & $1995-2004$ \\
\hline United Arab Emirates & \\
\hline USA & NA & $1901-2004$ \\
\hline Vietnam & \\
\hline Tambia number of observations for the unbalanced \\
is 226 and 222 for China and \\
\hline
\end{tabular}


Table 3: Descriptive statistics

\begin{tabular}{|c|c|c|c|c|c|c|c|}
\hline $\begin{array}{l}\text { Panel A: } \\
\text { Chinese data }\end{array}$ & \multicolumn{5}{|c|}{ Standard } & Minimum & Maximum \\
\hline FDI & 18.981 & 3.750 & 45.905 & 18.030 & 3.399 & -129.00 & 355.60 \\
\hline LNEXPORT & 20.731 & 21.300 & 2.299 & -0.771 & -0.457 & 15.675 & 24.792 \\
\hline LNIMPORT & 20.907 & 21.200 & 2.452 & 0.140 & -0.465 & 13.835 & 26.218 \\
\hline LNDISTANCE & 7.884 & 7.902 & 1.265 & 24.735 & -4.249 & 0.000 & 9.262 \\
\hline BUREAU & 2.723 & 3.000 & 1.137 & -0.894 & -0.414 & 0.000 & 4.000 \\
\hline CORRUPTION & 3.126 & 3.000 & 1.345 & -0.980 & 0.131 & 1.000 & 6.000 \\
\hline POLRISK & 72.079 & 72.000 & 12.344 & -0.380 & -0.462 & 41.000 & 95.000 \\
\hline TAX RATE & 0.306 & 0.308 & 0.079 & 1.829 & -1.215 & 0.090 & 0.460 \\
\hline INTEREST RATE & 6.607 & 6.025 & 10.073 & 12.464 & 1.037 & -41.680 & 70.740 \\
\hline $\begin{array}{l}\text { Panel B: } \\
\text { Indian data }\end{array}$ & Mean & Median & $\begin{array}{c}\text { Standard } \\
\text { Deviation }\end{array}$ & Kurtosis & Skewness & Minimum & Maximum \\
\hline FDI & 38.090 & 1.130 & 149.79 & 80.633 & 8.098 & -17.600 & 1741.9 \\
\hline LNEXPORT & 18.526 & 19.636 & 3.333 & 0.136 & -1.099 & 9.210 & 22.801 \\
\hline LNIMPORT & 19.366 & 19.921 & 2.323 & 0.174 & -0.815 & 12.644 & 23.657 \\
\hline LNDISTANCE & 7.892 & 7.856 & 0.589 & 0.007 & 0.031 & 6.217 & 8.922 \\
\hline BUREAU & 2.855 & 3.000 & 1.065 & -1.220 & -0.357 & 1.000 & 4.000 \\
\hline CORRUPTION & 3.171 & 3.000 & 1.359 & -1.122 & -0.084 & 1.000 & 6.000 \\
\hline POLRISK & 73.576 & 76.000 & 13.329 & -0.347 & -0.622 & 36.000 & 97.000 \\
\hline TAX RATE & 0.298 & 0.300 & 0.092 & 1.600 & -1.262 & 0.000 & 0.460 \\
\hline INTEREST RATE & 4.058 & 4.715 & 8.513 & 19.842 & -3.249 & -61.000 & 21.080 \\
\hline Panel C: & & & Standard & & & & \\
\hline Host countries & Mean & Median & Deviation & Kurtosis & Skewness & Minimum & Maximum \\
\hline GDPPC & 8.032 & 7.972 & 1.828 & -1.462 & -0.119 & 4.609 & 10.647 \\
\hline GDPGW & 4.253 & 4.300 & 3.626 & 3.223 & -0.575 & -13.10 & 13.800 \\
\hline LNGDP & 25.241 & 25.207 & 2.613 & -0.965 & 0.192 & 20.625 & 30.153 \\
\hline INFLATION & 7.371 & 3.435 & 14.214 & 32.522 & 5.032 & -4.000 & 128.40 \\
\hline EXCHANGE & 1514.5 & 25.525 & 3463.8 & 6.191 & 2.651 & 0.380 & 15704 \\
\hline RESOURCE & 5.889 & 1.345 & 12.551 & 11.496 & 3.331 & 0.000 & 73.450 \\
\hline LNFDI-STOCK & 21.046 & 23.155 & 5.985 & 0.449 & -1.295 & 4.852 & 28.579 \\
\hline MX/GDP & 0.035 & 0.011 & 0.058 & 14.438 & 3.397 & 0.000 & 0.432 \\
\hline
\end{tabular}

FDI is the foreign direct investment made by China (or India) to host countries, in millions \$US. LNEXPORT is the natural logarithm of the export from host country to China (or India). LNIMPORT is the natural logarithm of the import from host country to China (or India). LNDISTANCE is the natural logarithm of the geographical distance from the capital city of the host country to the capital of China (or India), in miles. BUREAU is the bureaucracy quality of the host country. CORRUPTION is the severity of corruption in the host country. POLRISK is the political risk in the host country. GDPPC is the natural logarithm of GDP per capita. GDPGW is the percentage GDP growth. LNGDP is the natural logarithm of GDP. INFLATION is the inflation rate. EXCHANGE is the exchange rate between \$US and host country's currency. RESOURCE is the proportion of natural resource endowment. LNFDI-STOCK is the natural logarithm of foreign direct investment stock, net of home country FDI stock. TAX RATE is the corporate tax rate of the host country. INTEREST RATE is the annual interest rate of the host country. MX/GDP is the ratio of exports plus imports to the GDP of the host country. 
Table 4: Correlation matrix for the main variables

\begin{tabular}{|c|c|c|c|c|c|c|c|c|c|c|c|c|c|c|}
\hline Panel A: China & FDI & GDPGW & LNGDP & INFL & EXCH & RESRC & LNEXP & LNIMP & LNDIS & FDI-STK & BUR & CORR & POL & TAX \\
\hline GDPGW & -0.060 & & & & & & & & & & & & & \\
\hline LNGDP & 0.119 & $-0.180^{b}$ & & & & & & & & & & & & \\
\hline INFLATION & -0.130 & 0.057 & $-0.240^{\mathrm{a}}$ & & & & & & & & & & & \\
\hline EXCHANGE & -0.051 & 0.129 & $-0.166^{\mathrm{a}}$ & $0.283^{\mathrm{a}}$ & & & & & & & & & & \\
\hline RESOURCE & -0.077 & -0.096 & $-0.356^{\mathrm{a}}$ & $0.232^{\mathrm{a}}$ & 0.000 & & & & & & & & & \\
\hline LNEXPORT & $0.223^{\mathrm{a}}$ & -0.099 & $0.825^{\mathrm{a}}$ & $-0.307^{\mathrm{a}}$ & -0.082 & $-0.458^{a}$ & & & & & & & & \\
\hline LNIMPORT & $0.207^{\mathrm{a}}$ & -0.042 & $0.799^{\mathrm{a}}$ & $-0.161^{b}$ & -0.025 & $-0.277^{\mathrm{a}}$ & $0.844^{\mathrm{a}}$ & & & & & & & \\
\hline LNDISTANCE & -0.028 & $-0.158^{b}$ & $0.193^{\mathrm{a}}$ & 0.051 & $-0.227^{\mathrm{a}}$ & $0.170^{b}$ & $-0.155^{\mathrm{b}}$ & $-0.164^{\mathrm{b}}$ & & & & & & \\
\hline LNFDI-STOCK & 0.079 & -0.011 & $0.458^{\mathrm{a}}$ & -0.132 & $0.154^{\mathrm{b}}$ & $-0.529^{\mathrm{a}}$ & $0.555^{\mathrm{a}}$ & $0.513^{\mathrm{a}}$ & $-0.229^{\mathrm{a}}$ & & & & & \\
\hline BUREAU & $-0.140^{b}$ & $0.278^{\mathrm{a}}$ & $-0.679^{\mathrm{a}}$ & $0.436^{\mathrm{a}}$ & $0.227^{\mathrm{a}}$ & $0.252^{\mathrm{a}}$ & $-0.658^{\mathrm{a}}$ & $-0.596^{\mathrm{a}}$ & -0.019 & $-0.426^{a}$ & & & & \\
\hline CORRUPTION & $-0.153^{b}$ & $0.252^{\mathrm{a}}$ & $-0.306^{\mathrm{a}}$ & $0.361^{a}$ & $0.285^{\mathrm{a}}$ & -0.034 & $-0.262^{\mathrm{a}}$ & $-0.247^{\mathrm{a}}$ & $-0.201^{a}$ & 0.021 & $0.599^{\mathrm{a}}$ & & & \\
\hline POLRISK & $-0.153^{b}$ & $0.209^{\mathrm{a}}$ & $-0.481^{\mathrm{a}}$ & $0.498^{\mathrm{a}}$ & $0.302^{\mathrm{a}}$ & 0.119 & $-0.388^{\mathrm{a}}$ & $-0.347^{\mathrm{a}}$ & -0.058 & $-0.182^{\mathrm{b}}$ & $0.786^{\mathrm{a}}$ & $0.740^{\mathrm{a}}$ & & \\
\hline TAX & -0.112 & -0.079 & $0.4366^{\mathrm{a}}$ & $0.165^{\mathrm{b}}$ & -0.036 & -0.021 & $0.231^{\mathrm{a}}$ & $0.163^{\mathrm{b}}$ & $0.436^{\mathrm{a}}$ & $0.183^{\mathrm{b}}$ & $0.151^{\mathrm{b}}$ & $0.228^{\mathrm{a}}$ & 0.089 & \\
\hline INTEREST & 0.041 & -0.035 & 0.015 & $-0.498^{a}$ & -0.018 & $0.209^{\mathrm{a}}$ & -0.024 & -0.024 & 0.030 & $-0.231^{\mathrm{a}}$ & -0.012 & 0.058 & 0.016 & $-0.155^{\mathrm{b}}$ \\
\hline Panel B: India & FDI & GDPGW & LNGDP & INFL & EXCH & RESRC & LNEXP & LNIMP & LNDIS & FDI-STK & BURE & CORR & POL & TAX \\
\hline GDPGW & 0.038 & & & & & & & & & & & & & \\
\hline LNGDP & 0.025 & $-0.198^{a}$ & & & & & & & & & & & & \\
\hline INFLATION & 0.067 & 0.094 & $-0.237^{\mathrm{a}}$ & & & & & & & & & & & \\
\hline EXCHANGE & -0.085 & 0.128 & -0.139 & $0.178^{b}$ & & & & & & & & & & \\
\hline RESOURCE & 0.082 & 0.092 & $0.155^{\mathrm{b}}$ & 0.021 & -0.025 & & & & & & & & & \\
\hline LNEXPORT & 0.022 & 0.039 & $0.745^{\mathrm{a}}$ & -0.015 & -0.135 & $0.173^{b}$ & & & & & & & & \\
\hline LNIMPORT & 0.079 & -0.063 & $0.810^{\mathrm{a}}$ & $-0.194^{a}$ & -0.063 & 0.062 & $0.859^{\mathrm{a}}$ & & & & & & & \\
\hline LNDISTANCE & 0.094 & $-0.214^{\mathrm{a}}$ & $0.378^{\mathrm{a}}$ & $-0.156^{\mathrm{b}}$ & $-0.155^{\mathrm{b}}$ & 0.139 & 0.095 & $0.190^{b}$ & & & & & & \\
\hline LNFDI-STOCK & 0.058 & $-0.141^{\mathrm{b}}$ & $0.772^{\mathrm{a}}$ & $-0.270^{\mathrm{a}}$ & -0.101 & $0.207^{\mathrm{a}}$ & $0.617^{\mathrm{a}}$ & $0.659^{\mathrm{a}}$ & $0.516^{\mathrm{a}}$ & & & & & \\
\hline BUREAU & $0.146^{b}$ & $0.365^{\mathrm{a}}$ & $-0.639^{\mathrm{a}}$ & $0.370^{\mathrm{a}}$ & $0.176^{b}$ & -0.079 & $-0.293^{a}$ & $-0.348^{\mathrm{a}}$ & $-0.461^{a}$ & $-0.687^{\mathrm{a}}$ & & & & \\
\hline CORRUPTION & 0.063 & $0.314^{\mathrm{a}}$ & $-0.501^{\mathrm{a}}$ & $0.311^{\mathrm{a}}$ & $0.265^{\mathrm{a}}$ & -0.116 & $-0.216^{a}$ & $-0.288^{a}$ & $-0.470^{\mathrm{a}}$ & $-0.542^{\mathrm{a}}$ & $0.770^{\mathrm{a}}$ & & & \\
\hline POLRISK & 0.098 & $0.263^{\mathrm{a}}$ & $-0.516^{\mathrm{a}}$ & $0.286^{\mathrm{a}}$ & $0.156^{\mathrm{b}}$ & -0.127 & -0.139 & $-0.166^{\mathrm{b}}$ & $-0.465^{\mathrm{a}}$ & $-0.642^{\mathrm{a}}$ & $0.852^{\mathrm{a}}$ & $0.769^{\mathrm{a}}$ & & \\
\hline TAX & $-0.154^{b}$ & $-0.177^{\mathrm{b}}$ & $0.347^{\mathrm{a}}$ & $0.163^{b}$ & 0.039 & 0.142 & $0.178^{b}$ & 0.136 & 0.148 & $0.183^{b}$ & 0.096 & $0.240^{\mathrm{a}}$ & 0.077 & \\
\hline INTEREST & -0.064 & 0.070 & 0.034 & $-0.585^{\mathrm{a}}$ & 0.075 & 0.031 & 0.026 & 0.121 & -0.027 & -0.012 & $0.169^{\mathrm{b}}$ & $0.184^{\mathrm{b}}$ & 0.117 & $-0.202^{\mathrm{a}}$ \\
\hline
\end{tabular}


Table 5: Determinants of outward FDI: Chinese and Indian data pooled

\begin{tabular}{|c|c|c|c|c|c|c|}
\hline Explanatory variables & $(1)$ & $(2)$ & $(3)$ & (4) & $(5)$ & (6) \\
\hline LNGDP & $\begin{array}{c}55.120 * * \\
(27.550)\end{array}$ & $\begin{array}{l}53.046 * * \\
(24.400)\end{array}$ & $\begin{array}{c}62.989 * * * \\
(23.550)\end{array}$ & - & - & - \\
\hline GDPGW & - & - & - & $\begin{array}{c}-2.9211^{* *} \\
(1.4470)\end{array}$ & $\begin{array}{c}-2.9604^{* * *} \\
(1.4530)\end{array}$ & $\begin{array}{c}-2.7849 * * \\
(1.3720)\end{array}$ \\
\hline OPENNESS & $\begin{array}{l}5.4721^{*} \\
(3.2470)\end{array}$ & $\begin{array}{l}6.0494 * \\
(3.5300)\end{array}$ & $\begin{array}{c}262.943 * * * \\
(98.510)\end{array}$ & $\begin{array}{c}255.463 * * * \\
(93.540)\end{array}$ & $\begin{array}{c}228.391 * * \\
(106.700)\end{array}$ & $\begin{array}{c}281.919 * * * \\
(81.320)\end{array}$ \\
\hline RESOURCE & $\begin{array}{l}-0.5553 \\
(1.1210)\end{array}$ & $\begin{array}{l}-0.3863 \\
(1.0650)\end{array}$ & $\begin{array}{l}-2.4474 \\
(1.6360)\end{array}$ & $\begin{array}{l}-2.6543 \\
(1.7170)\end{array}$ & $\begin{array}{l}-2.3853 \\
(1.7940)\end{array}$ & $\begin{array}{c}-1.9764 \\
(1.4730)\end{array}$ \\
\hline LNEXPORT & $\begin{array}{l}-1.9473 \\
(3.1790)\end{array}$ & $\begin{array}{l}-2.0893 \\
(3.3060)\end{array}$ & $\begin{array}{l}-1.4626 \\
(2.4500)\end{array}$ & $\begin{array}{c}2.0642 \\
(3.9620)\end{array}$ & - & - \\
\hline LNIMPORT & - & - & - & - & $\begin{array}{c}10.2365^{*} \\
(6.0670)\end{array}$ & $\begin{array}{l}8.2496^{*} \\
(4.4520)\end{array}$ \\
\hline EXCHANGE & $\begin{array}{c}0.0023 \\
(0.0020)\end{array}$ & $\begin{array}{c}-0.0002 \\
(0.0007)\end{array}$ & $\begin{array}{l}-0.0001 \\
(0.0008)\end{array}$ & $\begin{array}{c}0.0014 \\
(0.0016)\end{array}$ & $\begin{array}{c}0.0010 \\
(0.0017)\end{array}$ & $\begin{array}{c}0.0031 \\
(0.0022)\end{array}$ \\
\hline POLRISK & $\begin{array}{c}2.8072 * * \\
(1.3860)\end{array}$ & - & - & $\begin{array}{c}2.9146 * * \\
(1.4190)\end{array}$ & $\begin{array}{c}2.9962 * * \\
(1.4440)\end{array}$ & $\begin{array}{c}3.7136 * * \\
(1.8431)\end{array}$ \\
\hline BUREAU & - & $\begin{array}{c}0.6721 \\
(5.3480)\end{array}$ & - & - & - & - \\
\hline CORRUPTION & - & - & $\begin{array}{l}7.9415^{*} \\
(4.4500)\end{array}$ & - & - & - \\
\hline LNDISTANCE & $\begin{array}{c}-102.961 * \\
(56.650)\end{array}$ & $\begin{array}{c}-105.025^{*} \\
(59.820)\end{array}$ & $\begin{array}{c}-77.104 * \\
(43.190)\end{array}$ & $\begin{array}{c}-72.831 * \\
(40.510)\end{array}$ & $\begin{array}{c}-84.568 * * \\
(40.980)\end{array}$ & $\begin{array}{c}-63.587 * * \\
(29.880)\end{array}$ \\
\hline INFLATION & $\begin{array}{l}-0.1224 \\
(0.2494)\end{array}$ & - & $\begin{array}{l}-0.1679 \\
(0.3000)\end{array}$ & $\begin{array}{l}-0.4528^{*} \\
(0.2740)\end{array}$ & - & - \\
\hline TAX RATE & $\begin{array}{c}-0.7157^{* *} * \\
(0.3572)\end{array}$ & $\begin{array}{c}-0.5567^{* *} \\
(0.2635)\end{array}$ & $\begin{array}{c}-1.0705^{* * * *} \\
(0.4122)\end{array}$ & $\begin{array}{c}-1.8290 * * * \\
(0.6769)\end{array}$ & $\begin{array}{c}-1.6726 * * * \\
(0.6195)\end{array}$ & $\begin{array}{c}-0.0799 \\
(0.1914)\end{array}$ \\
\hline INTEREST RATE & - & $\begin{array}{l}-0.1056 \\
(0.3386)\end{array}$ & - & - & $\begin{array}{c}0.1472 \\
(0.2683)\end{array}$ & $\begin{array}{c}0.3512 \\
(0.2144)\end{array}$ \\
\hline CHINA DUMMY & $\begin{array}{c}356.666 * * * \\
(119.300)\end{array}$ & $\begin{array}{c}351.047 * * * \\
(116.300)\end{array}$ & $\begin{array}{c}276.142^{* *} \\
(113.600)\end{array}$ & $\begin{array}{c}269.181 * * \\
(128.100)\end{array}$ & $\begin{array}{c}228.742 * * \\
(109.200)\end{array}$ & $\begin{array}{c}657.538 * * \\
(295.800)\end{array}$ \\
\hline OECD DUMMY & $\begin{array}{c}-250.864 * \\
(147.000)\end{array}$ & $\begin{array}{c}-268.693^{*} \\
(142.300)\end{array}$ & $\begin{array}{l}-109.608 \\
(133.400)\end{array}$ & $\begin{array}{c}-199.910 * * \\
(86.320)\end{array}$ & $\begin{array}{c}-196.788 * * * \\
(72.410)\end{array}$ & $\begin{array}{c}-112.211^{*} \\
(70.030)\end{array}$ \\
\hline GDPGW x GROWTH DUMMY & - & - & - & $\begin{array}{c}4.4250^{* *} \\
(2.1910)\end{array}$ & $\begin{array}{l}4.6401^{*} \\
(2.5780)\end{array}$ & $\begin{array}{l}5.0424 * * \\
(2.1860)\end{array}$ \\
\hline EXCHANGE x CHINA DUMMY & $\begin{array}{c}-0.0004 \\
(0.0012)\end{array}$ & $\begin{array}{c}-0.0004 \\
(0.0012)\end{array}$ & $\begin{array}{c}0.0012 \\
(0.0012)\end{array}$ & $\begin{array}{c}0.0012 \\
(0.0013)\end{array}$ & $\begin{array}{c}0.0010 \\
(0.0012)\end{array}$ & $\begin{array}{c}0.0012 \\
(0.0018)\end{array}$ \\
\hline LNDISTANCE x CHINA DUMMY & $\begin{array}{c}-45.064 * * * \\
(14.720)\end{array}$ & $\begin{array}{c}-44.211 * * * \\
(14.340)\end{array}$ & $\begin{array}{c}-38.434 * * * \\
(14.940)\end{array}$ & $\begin{array}{c}-39.048 * * \\
(16.050)\end{array}$ & $\begin{array}{c}-35.807 * * \\
(15.950)\end{array}$ & $\begin{array}{c}-86.843 * * \\
(39.370)\end{array}$ \\
\hline No. of observations & 448 & 448 & 448 & 448 & 448 & 396 \\
\hline $\mathrm{R}^{2} /$ Adjusted $\mathrm{R}^{2}$ & $0.358 / 0.259$ & $0.351 / 0.252$ & $0.359 / 0.260$ & $0.345 / 0.243$ & $0.346 / 0.244$ & $0.392 / 0.283$ \\
\hline F statistics & $270.6^{* * *}$ & $59.24 * * *$ & $268.5 * * *$ & $217.4 * * *$ & $1282 * * *$ & $107.4 * * *$ \\
\hline
\end{tabular}

See notes to Table 2 for variable definitions. CHINA DUMMY is 1 if the observation belongs to Chinese outward FDI; 0, otherwise. OECD DUMMY is 1 if the host country is a member of OECD; 0 , otherwise The dependent variable is FDI. The estimated standard errors robust to heteroscedasticity are in the parentheses. $* * *, * *$, and $*$ denotes significance level at the $1 \%, 5 \%$, and $10 \%$ level, respectively. OPENNESS is measured by LNFDI-STOCK in models 1, 2; and by MX/GDP in other models. GROWTH DUMMY is 1 if GDPGW is negative; 0 , otherwise. In model 6, we dropped the US data. 
Table 6: Determinants of outward FDI: Chinese and Indian data decomposed

\begin{tabular}{|c|c|c|c|c|c|c|}
\hline & \multicolumn{3}{|c|}{ China } & \multicolumn{3}{|c|}{ India } \\
\hline & (1) & $(2)$ & (3) & (4) & $(5)$ & (6) \\
\hline LNGDP & $\begin{array}{c}57.814 * * * \\
(22.150)\end{array}$ & $\begin{array}{c}34.319^{* *} \\
(16.910)\end{array}$ & - & $\begin{array}{l}32.483^{*} \\
(19.101)\end{array}$ & $\begin{array}{c}-5.5567 \\
(100.600)\end{array}$ & - \\
\hline GDPGW & - & - & $\begin{array}{c}-3.2876^{* *} \\
(1.4560)\end{array}$ & - & - & $\begin{array}{c}-2.6299 * \\
(1.4460)\end{array}$ \\
\hline OPENNESS & $\begin{array}{l}388.965^{*} \\
(223.200)\end{array}$ & $\begin{array}{l}188.913^{*} \\
(114.500)\end{array}$ & $\begin{array}{c}86.242 \\
(243.500)\end{array}$ & $\begin{array}{l}-170.841 \\
(393.800)\end{array}$ & $\begin{array}{c}-952.062 \\
(684.400)\end{array}$ & $\begin{array}{r}-1051.240 \\
(803.000)\end{array}$ \\
\hline RESOURCE & $\begin{array}{c}-0.5244 \\
(0.6129)\end{array}$ & $\begin{array}{c}-0.7323 \\
(0.5101)\end{array}$ & $\begin{array}{l}-0.3846 \\
(0.5794)\end{array}$ & $\begin{array}{c}-0.6514 \\
(4.9580)\end{array}$ & $\begin{array}{c}-0.2458 \\
(5.7710)\end{array}$ & $\begin{array}{c}1.4496 \\
(5.1150)\end{array}$ \\
\hline LNEXPORT & $\begin{array}{c}-18.9343 \\
(12.2000)\end{array}$ & - & - & $\begin{array}{c}3.7335 \\
(11.4800)\end{array}$ & - & - \\
\hline LNIMPORT & - & $\begin{array}{c}0.5073 \\
(7.9690)\end{array}$ & $\begin{array}{l}8.9670^{*} \\
(5.1260)\end{array}$ & - & $\begin{array}{c}29.2702 * \\
(17.550)\end{array}$ & $\begin{array}{l}30.654^{*} \\
(16.980)\end{array}$ \\
\hline EXCHANGE & $\begin{array}{c}0.0029 * * \\
(0.0014)\end{array}$ & $\begin{array}{c}0.0025^{* *} \\
(0.0012)\end{array}$ & $\begin{array}{c}0.0020^{* *} \\
(0.0010)\end{array}$ & $\begin{array}{c}0.0001 \\
(0.0032)\end{array}$ & $\begin{array}{l}-0.0017 \\
(0.0029)\end{array}$ & $\begin{array}{c}-0.0023 \\
(0.0044)\end{array}$ \\
\hline POLRISK & $\begin{array}{c}1.9527 * * \\
(0.9750)\end{array}$ & $\begin{array}{c}2.0724 * * \\
(1.0400)\end{array}$ & $\begin{array}{l}1.9245^{* *} \\
(0.9430)\end{array}$ & $\begin{array}{c}1.5917 \\
(2.0690)\end{array}$ & $\begin{array}{c}1.3406 \\
(2.1270)\end{array}$ & $\begin{array}{c}1.3477 \\
(2.4010)\end{array}$ \\
\hline LNDISTANCE & $\begin{array}{c}-5.4974 * * * \\
(2.0060)\end{array}$ & $\begin{array}{c}-4.1362 * * \\
(2.0520)\end{array}$ & $\begin{array}{l}-35.2733^{*} \\
(20.1500)\end{array}$ & $\begin{array}{c}14.7270 \\
(111.200)\end{array}$ & $\begin{array}{c}54.078 \\
(106.800)\end{array}$ & $\begin{array}{c}44.913 \\
(89.350)\end{array}$ \\
\hline INFLATION & $\begin{array}{c}0.0892 \\
(0.1376)\end{array}$ & $\begin{array}{c}0.0490 \\
(0.1125)\end{array}$ & $\begin{array}{c}-0.0329 \\
(0.0810)\end{array}$ & $\begin{array}{c}0.2371 \\
(0.4629)\end{array}$ & $\begin{array}{c}0.2325 \\
(0.4364)\end{array}$ & $\begin{array}{c}0.2079 \\
(0.1760)\end{array}$ \\
\hline TAX RATE & $\begin{array}{c}-162.310^{* *} \\
(66.500)\end{array}$ & $\begin{array}{c}-98.067 * \\
(56.560)\end{array}$ & $\begin{array}{l}-84.189 * \\
(48.250)\end{array}$ & $\begin{array}{l}-664.946^{*} \\
(391.020)\end{array}$ & $\begin{array}{l}-676.21 * \\
(397.01)\end{array}$ & $\begin{array}{l}-635.574 * \\
(371.100)\end{array}$ \\
\hline LANGUAGE DUMMY & $\begin{array}{l}42.674 * \\
(25.104)\end{array}$ & $\begin{array}{c}86.555^{* *} \\
(43.440)\end{array}$ & $\begin{array}{l}90.430 * \\
(54.490)\end{array}$ & $\begin{array}{c}-8.1041 \\
(117.800)\end{array}$ & $\begin{array}{c}47.9749 \\
(152.100)\end{array}$ & $\begin{array}{c}36.997 \\
(110.600)\end{array}$ \\
\hline OECD DUMMY & $\begin{array}{c}-171.394 * \\
(97.770)\end{array}$ & $\begin{array}{c}-107.968^{*} \\
(62.970)\end{array}$ & $\begin{array}{l}-70.150 \\
(70.920)\end{array}$ & $\begin{array}{l}-149.171 \\
(813.000)\end{array}$ & $\begin{array}{c}-90.0857 \\
(709.800)\end{array}$ & $\begin{array}{l}-137.378 \\
(308.400)\end{array}$ \\
\hline GDPGW x GROWTH DUMMY & - & - & $\begin{array}{c}6.5789 * * * \\
(2.2850)\end{array}$ & - & - & $\begin{array}{l}2.4586^{*} \\
(1.4740)\end{array}$ \\
\hline No. of observations & 226 & 226 & 226 & 222 & 222 & 222 \\
\hline $\mathrm{R}^{2} /$ Adjusted $\mathrm{R}^{2}$ & $0.330 / 0.172$ & $0.312 / 0.151$ & $0.334 / 0.175$ & $0.458 / 0.331$ & $0.462 / 0.333$ & $0.465 / 0.334$ \\
\hline F statistics & $920.6^{* * * *}$ & $1976 * * *$ & $2364 * * *$ & $4550 * * *$ & $8436 * * *$ & $4583 * * *$ \\
\hline
\end{tabular}

See notes to Tables 2 and 5 for variable definitions. The dependent variable is FDI. The estimated standard errors robust to heteroscedasticity are in the parentheses. $* * *, * *$, and $*$ denotes significance level at the $1 \%, 5 \%$, and $10 \%$ level, respectively. OPENNESS is measured by MX/GDP in all models. LANGUAGE DUMMY is 1 if the official language of the host country is English; 0, otherwise. 